\title{
Effects of fishing, market price, and climate on two South American clam species
}

\author{
Leonardo Ortega ${ }^{1}$, Juan Carlos Castilla ${ }^{2}$, Marco Espino ${ }^{3}$, Carmen Yamashiro ${ }^{3}$, \\ Omar Defeo ${ }^{1,4, *}$
}

\author{
${ }^{1}$ Dirección Nacional de Recursos Acuáticos (DINARA), Constituyente 1497, 11200 Montevideo, Uruguay \\ ${ }^{2}$ Departamento de Ecología, Facultad de Ciencias Biológicas and Centro Interdisciplinario de Cambio Global, \\ Pontificia Universidad Católica de Chile, Casilla 114-D, Santiago, Chile \\ ${ }^{3}$ Instituto del Mar del Perú, Apartado 22, Callao, Perú \\ ${ }^{4}$ Unidad de Ciencias del Mar (UNDECIMAR), Facultad de Ciencias, Iguá 4225, 11400 Montevideo, Uruguay
}

\begin{abstract}
Coastal shellfish are being threatened by several drivers acting at multiple temporal and spatial scales, including fishing, climate, and globalization of markets. We evaluated largescale and long-term combined effects of fishing, climate, and economic variables on 2 congeneric clams that inhabit sandy beaches of the Pacific (Mesodesma donacium) and the Atlantic (M. mactroides) in South America. Bioeconomic and climatic variables, such as coastal sea surface temperature anomalies (SSTA) and broad-scale climatic indices (Pacific Decadal Oscillation and Atlantic Multidecadal Oscillation), were related to variations in clam populations in a differential way according to latitude and oceanographic features. For $M$. donacium, the nature and sign of the relationships between landings and explanatory predictors markedly differed between bioclimatic units. El Niño Southern Oscillation events negatively affected landings in Peru and northern Chile, whereas landings increased in southern Chile and showed a positive correlation with increasing SSTA, suggesting a positive effect at the southernmost edge of the species distribution. Long-term trends in the abundance of M. mactroides were related to fishing intensity and SSTA. As anticipated by basic economic theory, deficit of supply relative to demand, exacerbated by very low harvesting costs, pushed the price up and has driven these clam species to levels close to extinction (anthropogenic Allee effect). The lack of response of the stocks to long-term closures suggests that these systems exceeded critical thresholds (tipping points). Information on early warnings of tipping points is needed to help manage coastal shellfisheries that are increasingly threatened by long-lasting and large-scale stressors.
\end{abstract}

KEY WORDS: Intertidal clams $\cdot$ Sandy beaches $\cdot$ Climate variability $\cdot$ Fisheries bioeconomics

\section{INTRODUCTION}

Many small-scale shellfisheries in the world are data-poor and have critical socioeconomic connotations worldwide (Caddy \& Defeo 2003, McClanahan et al. 2009). In Latin America, these fisheries are based on high-value species and represent sources of food for subsistence and employment, generating important direct incomes to fisher communities and, in some cases, export earnings (Castilla \& Defeo 2001). However, shellfisheries sustainability has been difficult to achieve. Nowadays, many shellfish populations in Latin America are overexploited or depleted (Carranza et al. 2009a, b). In addition to local drivers affecting shellfish condition, global change drivers have exacerbated stock depletion rates, particularly (Defeo \& Castilla 2005, 2012, Beck et al. 2011, Perry et al. 2011): (1) increasing prices for shellfish highly em- 
bedded in global markets, and (2) climate variability, such as temperature rise. Thus, the resilience of these social-ecological systems can be degraded by several drivers acting simultaneously (Ling et al. 2009, Miller et al. 2010). However, the integration of biophysical and socioeconomic information in long-term fisheries modeling has been more complex than previously thought (Cury et al. 2008).

Climatic processes have drastic effects in the functioning of marine biological systems at a wide range of temporal and spatial scales (e.g. Bakun 1996, Rouyer et al. 2008). Ocean climate variables, such as shifting currents and temperature changes, alter feeding, growth, and migratory patterns of marine fauna (Miller et al. 2010). In South America, these scenarios are related to interannual (e.g. El Niño Southern Oscillation [ENSO]) and multidecadal (e.g. Pacific Decadal Oscillation [PDO] and Atlantic Multidecadal Oscillation [AMO]) environmental variability associated with broad-scale oceanic climatic variations, which influence currents and water mass properties. This atmospheric-oceanic multiscale variability affects ecosystems, including their fishery resources (Chavez et al. 2003, Montecino \& Lange 2009).

The effects of climate change may be profoundly felt in the macrofauna present in sandy beaches, a largely forgotten ecosystem despite its coverage of $>70 \%$ of the open coasts of the world (Defeo et al. 2009). The position at the land-sea margin renders sandy beaches highly vulnerable to climate change, being at risk of significant habitat loss and ecological impacts from warming and erosion caused by sealevel rise and increased storms (Dugan et al. 2010). These cumulative effects are also exacerbated by the extraction of easily accessible and high-value resources inhabiting intertidal sandy shores, notably clams (McLachlan et al. 1996). Although these fisheries are generally of small scale, fishing impacts can be significant and can be amplified or reinforced by: (1) continuous erosion of beaches that reduced clam habitats (Beentjes et al. 2006), and (2) mass mortalities (Fiori et al. 2004, Riascos et al. 2009).

Sandy beach clams of the genus Mesodesma are a valuable resource along the Atlantic and Pacific coasts of South America (Defeo 2003). Humans have been harvesting these marine invertebrates for a long time (Rivadeneira et al. 2010). In the Pacific, the surf clam $M$. donacium (macha) is one of the most important shellfishes exploited in Chile and Peru, even though it is also a data-poor fishery where effective fishing-effort estimates are rarely available. In the Atlantic, the yellow clam $M$. mactroides is commercially exploited in sandy beaches of Brazil, Uruguay, and
Argentina (Herrmann et al. 2011). The genus Mesodesma has an Antarctic origin and can be associated with cold water systems, both in the Pacific and Atlantic. This genus invaded South American coasts in the late Pliocene or possibly in the early Pleistocene, during a major migration of mollusks from Antarctica, following 2 cold currents: Malvinas on the east coast and the Humboldt Current System (HCS) on the west coast (von Ihering 1907). This migration was probably triggered by decreasing temperatures at the end of the Tertiary and early Quaternary periods. According to von Ihering (1907), the dispersion of $M$. mactroides on the Patagonian coast occurred during the Pleistocene and has only recently encompassed the Brazilian littoral, delayed by the strong zoogeographic barrier represented by the Rio de la Plata (Marins \& Levy 1999). These filter-feeding clams inhabit the intertidal and shallow subtidal zones of exposed, high-energy dissipative sandy beaches, where they typically burrow to a depth $\sim 30 \mathrm{~cm}$ (McLachlan et al. 1996).

Mass mortalities decimated populations of both Mesodesma species along their entire geographic ranges during the last $30 \mathrm{yr}$. These mass mortalities have been attributed to a number of factors, namely positive sea temperature anomalies, harmful algal blooms, environmental stress, parasitism, and storms (Odebrecht et al. 1995, Fiori et al. 2004, Riascos et al. 2009, 2011, Carstensen et al. 2010). In the case of $M$. mactroides, it has been suggested that the effect of these mortalities may swamp management measures (Defeo 2003). However, large-scale and long-term records that could be used to evaluate the relative importance of climate and fishing in these sandy beach species are lacking. In the present paper, we evaluate the relative explanatory power of fishing and climate variability in explaining long-term fishery and abundance trends in $M$. donacium and $M$. mactroides clams. We focused on 3 key issues that rule the discussions in fisheries nowadays (Defeo \& Castilla 2012): (1) the role of climate in fisheries landings, (2) the effects of fishing, and (3) market prices as drivers in the fate of stocks.

\section{MATERIALS AND METHODS}

\section{Study area and ecological settings}

\section{Mesodesma donacium}

The surf clam Mesodesma donacium (Lamarck, 1818) is one of the most important bivalves harvested 
in Pacific sandy beaches of South America. The species is distributed from Sechura Bay, Peru $\left(5^{\circ} \mathrm{S}\right.$; Álamo \& Valdivieso 1997$)$ to southern Chile $\left(\sim 42^{\circ} \mathrm{S}\right.$; Tarifeño 1980) (Fig. 1). M. donacium often exhibits high densities and extremely high annual production, representing $>95 \%$ of the biomass in the shallow soft-bottom community (Arntz et al. 1987). The across-shore distribution of $M$. donacium is patchy and adult clams are primarily confined to the surf zone, while the vast majority of juveniles occur in the swash zone (Tarifeño 1980, Jaramillo et al. 1994). In Chile, surf clams constitute a sequential fishery (sensu Seijo et al. 1998), with 2 groups of artisanal fishers spatially segregated: (1) fishers who manually collect clams from the intertidal and shallow subtidal beach fringes during low tides, and (2) 'hookah' divers that use small deckless boats with air compressors to extract clams located at the surf zone. In Peru, the macha is extracted both manually in the intertidal by digging with shovels and dredges in the shallow subtidal (Ibarcena et al. 2005).

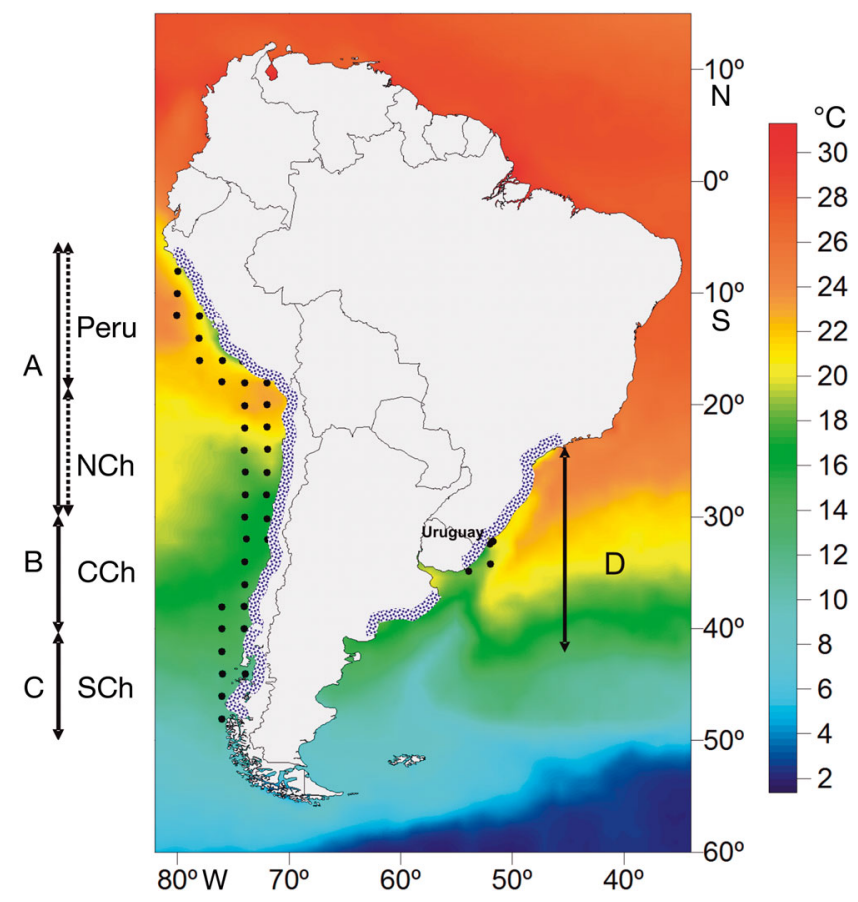

Fig. 1. Geographic distribution of the genus Mesodesma along the coasts of South America (purple stipple), highlighting the bioclimatic units: (A) subtropical-temperate, including 2 sub-units, Peru and Northern Chile (NCh); (B) transitional (Central Chile: $\mathrm{CCh}$ ); (C) subantarctic (Southern Chile: $\mathrm{SCh})$; and (D) the Warm-Temperate Southwestern Atlantic province. $\bullet$ : locations where sea surface temperature anomalies derived from Reynolds et al. (2002) were obtained. The satellite image is an annual composite (1996) of sea surface temperature (color scale in ${ }^{\circ} \mathrm{C}$ ) derived from the Moderate-

Resolution Imaging Spectroradiometer (MODIS-Aqua)
Environmental conditions in the HCS are broadly characterized by nutrient-rich, cool waters, showing slight seasonal temperature variability compared to those found in other coastal ecosystems at similar latitudes (Camus 2001, Thiel et al. 2007). The influence of the continuous upwelling of cold subsurface waters, mainly at northern Chile and Peru, and seasonal upwelling in southern-central Chile (Thiel et al. 2007), causes an atypical weak north-south temperature gradient and extends the influence of cold environmental conditions northward (Camus 2001). Therefore, many species in the HCS exhibit broad distributional ranges and are adapted to moderately constant low water temperatures (Riascos et al. 2009).

According to Thiel et al. (2007), 3 bioclimatic units can be distinguished within the HCS (Fig. 1): (1) a northern unit, dominated by subtropical and temperate biota, extending from Peru to Northern-Central Chile $\left(4^{\circ} \mathrm{S}\right.$ to $30^{\circ} \mathrm{S}$ ) (where $\mathrm{NCh}$ is Northern Chile); (2) a transitional unit (Central Chile or $\mathrm{CCh}: 30^{\circ} \mathrm{S}$ to $40^{\circ} \mathrm{S}$ ), characterized by strong numerical reductions in subantarctic and subtropical species; and (3) a southern unit (Southern Chile or SCh: $40^{\circ} \mathrm{S}$ to $50^{\circ} \mathrm{S}$ ), dominated by subantarctic and temperate biota, extending from the Chilean archipelago to the Magellan Province.

\section{Mesodesma mactroides}

The yellow clam Mesodesma mactroides Reeve, 1854 , is found in sandy shores of the Warm-Temperate Southwestern Atlantic (WTSA) province of South America (Spalding et al. 2007), from Brazil $\left(24^{\circ} \mathrm{S}\right)$ to Argentina $\left(41^{\circ} \mathrm{S}\right)$ (Fiori \& Defeo 2006; our Fig. 1). This fast-growing, short-lived species $(<4 \mathrm{yr})$ is artisanally exploited (shovels and hand-picking) in the intertidal of sandy beaches from Brazil, Uruguay, and Argentina (Defeo 2003).

The WTSA is characterized by a marked seasonality, with predominance of Subantarctic Water during the cold period (austral winter-spring) and Tropical Water and Subtropical Shelf Water in the warm period (summer-autumn) (Lima et al. 1996, Piola et al. 2000, Ortega \& Martínez 2007). The area located over the shelf $\left(27^{\circ} \mathrm{S}\right.$ to $\left.35^{\circ} \mathrm{S}\right)$ is controlled by winter intrusions of Subantarctic Water along with Rio de la Plata and Patos-Mirim discharges, and has large annual sea surface temperature (SST) ranges $\left(7\right.$ to $\left.10^{\circ} \mathrm{C}\right)$ and an extremely high secular trend toward warming $(1.2$ to $1.6^{\circ} \mathrm{C}$ per $100 \mathrm{yr}$ ), especially in the proximity of estuaries (Zavialov et al. 1999). In austral winter, the 
occurrence of a thermal front separates warm tropical water associated with the Brazil Current and cold Subantarctic Water flowing northward on the shelf with an admixture of coastal freshwater discharges. In summer, shelf break coastal upwellings have been registered along the coast (Podestá 1990), particularly around Cabo Frio $\left(22^{\circ} \mathrm{S}\right)$ and Ilha de Sao Sebastiao $\left(24^{\circ} \mathrm{S}\right)$, at the northernmost limit of the yellow clam distribution. These upwellings pump up oxygen and nutrient-rich South Atlantic Central Water to the euphotic zones in the inner continental shelf, and weaken considerably during the austral winter (Piola et al. 2000). The southernmost distribution limit of the yellow clam is characterized by a major influence of oceanic cold waters (Guerrero et al. 2010).

\section{Data analysis}

SST anomalies (SSTA) for the Pacific and Atlantic coastal regions were estimated by the monthly-average gridded $0.5^{\circ}$ latitude by $0.5^{\circ}$ longitude recorded by Reynolds et al. (2002). The annual mean SSTA was also determined by biogeographic unit (Fig. 1). Since the northern bioclimatic unit in the Pacific was divided into NCh and Peru (see 'Study area and ecological settings'), the same methodology was applied to estimate mean SSTA for each sub-unit. Long-term biological information for the yellow clam in the Atlantic was available only for the eastern coast of Uruguay, and thus SSTA were estimated for this specific area.

Two broad-scale climate indices were used to represent large-scale processes that may influence clam abundance: the AMO and PDO. PDO and AMO time series were taken from www.esrl.noaa.gov/psd/data/ climateindices/list/. Standardized PDO values are derived from monthly SSTA in the North Pacific Ocean, poleward of $20^{\circ} \mathrm{N}$. In order to estimate PDO values, monthly mean global SSTA are removed to separate this effect from any 'global warming' signal that may be present in the data (Zhang et al. 1997). The AMO is a climate pattern of long-duration changes in the SST of the North Atlantic Ocean, with identifiable characteristics, specific regional effects, and often oscillatory behavior, which has its principal expression in the SST field (Enfield et al. 2001). As such, the AMO presents cool and warm phases that may last for 20 to $40 \mathrm{yr}$ at a time. A cumulative sum (annual mean values) of the AMO and PDO indices was used to detect sustained shifts in climate, marked by changes in slope of the cumulative sum plot (Fiedler 2002).
Long-term Mesodesma donacium landings from Chile (1966 to 2009) and Peru (1970 to 2009) were discriminated by bioclimatic unit. To this end, annual landings (clam catch that is put ashore) from 16 regions in Peru and 12 regions in Chile were assigned to the corresponding unit (no information on fishing effort is available). Peruvian landings were obtained from official sources (e.g. Ministerio de Pesquería del Perú, Ministerio de la Producción de Perú). For Chile, official landings were obtained from the Servicio Nacional de Pesca (SERNAP), and exportation volumes (tons or t) and economic revenues (US\$) were obtained from the Servicio Nacional de Aduanas (Chile). Unit export prices were obtained by the ratio between economic revenues and exportation volumes. Given the marked temporal differences in the development of fishery phases (sensu Castilla \& Defeo 2001) and also in SSTA trends (see 'Results') between NCh and Peru (subtropical-temperate bioclimatic unit), data from these 2 sub-units were analyzed separately.

Concerning the yellow clam Mesodesma mactroides, a long-term analysis was carried out only for Uruguay. The lack of statistical coverage in Brazil and Argentina precluded a more comprehensive analysis throughout this species' distribution range. In Uruguay, the yellow clam fishery is developed only along a $22 \mathrm{~km}$ sandy beach fringe located between La Coronilla and Barra del Chuy (Defeo 2003). Yellow clam abundance, estimated as the number of individuals per strip transect (ind. $\cdot \mathrm{m}^{-1}$ ), were obtained from seasonal surveys carried out during 27 consecutive years (1982 to 2008), according to a systematic design developed to quantify the stock (see Defeo 1996 for details). All clams retained in each sample were measured (maximum valve length) and counted, covering the full range of individual sizes (1 to $76 \mathrm{~mm}$ ). Annual abundance estimates were obtained by averaging seasonal estimates, which were provided for the whole population and also for the harvestable stock (individuals $>50 \mathrm{~mm}$; Defeo 1996). Concerning fishery-dependent statistics, daily information on catch, effective fishing effort (hours), and unit price paid by middlemen to fishers (the product is sold only in the local market) was collected on a per-fisher basis (Defeo 1996).

Generalized additive models (GAM; Hastie \& Tibshirani 1990) were used to assess the relationship between landings (surf clam: Peru and Chile) or abundance (yellow clam: Uruguay) and predictor variables: SSTA and unit price were used in the 
former, whereas SSTA and effective fishing effort were used in the latter. Taking into account the relatively short time period when the yellow clam fishery was active (see 'Results'), unit price was not considered for modeling purposes. In both cases, time of fishery development (in years) was also included as an independent variable in order to explore long-term trends in partial residuals. Partial residuals remove the effects of all the other variables from the dependent variable and therefore can be used to model the effects against predictors (Xiang 2001). A moving average of landings with a period of $3 \mathrm{yr}$ was performed to model macha landings in the Pacific. All models were estimated using the functions GAM (model building) and mgcv (estimation of smoothing parameters) included in $\mathrm{R}$ statistical software (R Development Core Team 2008). Smoothing parameters and degrees of freedom of the functions were estimated using the generalized cross-validation, and penalized cubic regression splines were used as smooth terms (Wood 2006). Different models were evaluated by the significant difference of residual deviance using the F-test. The final model was selected according to the level of deviance explained and Akaike's information criterion (AIC). Non-significant terms $(p>0.05)$ were dropped from the model. Additional analyses were performed involving only landings (Mesodesma donacium in Chile) or abundance ( $M$. mactroides in Uruguay) with price and fishing effort, respectively. The residuals of these models (i.e. the variance not explained by unit price or fishing effort) were modeled against SSTA to test if this climatic variable could account for the variance not explained by the model mentioned before.

\section{RESULTS}

\section{Multidecadal basin scale}

\section{Mesodesma donacium}

The cumulative sum of the PDO showed a marked shift in the ocean-climate regime from a cold to a warm phase in 1977 (Fig. 2A). Mesodesma donacium landings in Peru and NCh linearly increased with PDO $\left(\mathrm{r}^{2}=0.28, \mathrm{p}<0.05\right.$ and $\mathrm{r}^{2}=0.24, \mathrm{p}<0.001$, respectively), being low during the cold phase and increasing during the warm phase (Fig. 2B,C). By contrast, landings from $\mathrm{CCh}$ and $\mathrm{SCh}$ showed no significant correlations with PDO.

\section{Mesodesma mactroides}

The cumulative sum of the AMO showed a regime shift between 1994 and 1995 (Fig. 3A). This climatic index was positively correlated with SSTA recorded for the study zone $\left(r^{2}=0.39, p<0.005\right)$, displaying the best fit with a lag of 4 yr between them (i.e. $\operatorname{SST}_{(t+4)}$ vs. $\left.\mathrm{AMO}_{(t)}\right)$ (Fig. 3B). Yellow clam abundance was inversely correlated with AMO variations, displaying the best fit with a lag of 4 yr (i.e. abundance $(t+4)$ vs. $\left.\mathrm{AMO}_{(t) ;} \mathrm{r}^{2}=0.19, \mathrm{p}<0.05\right)$, meaning higher abundance during the cold period and lower during the warm one (Fig. 3C).
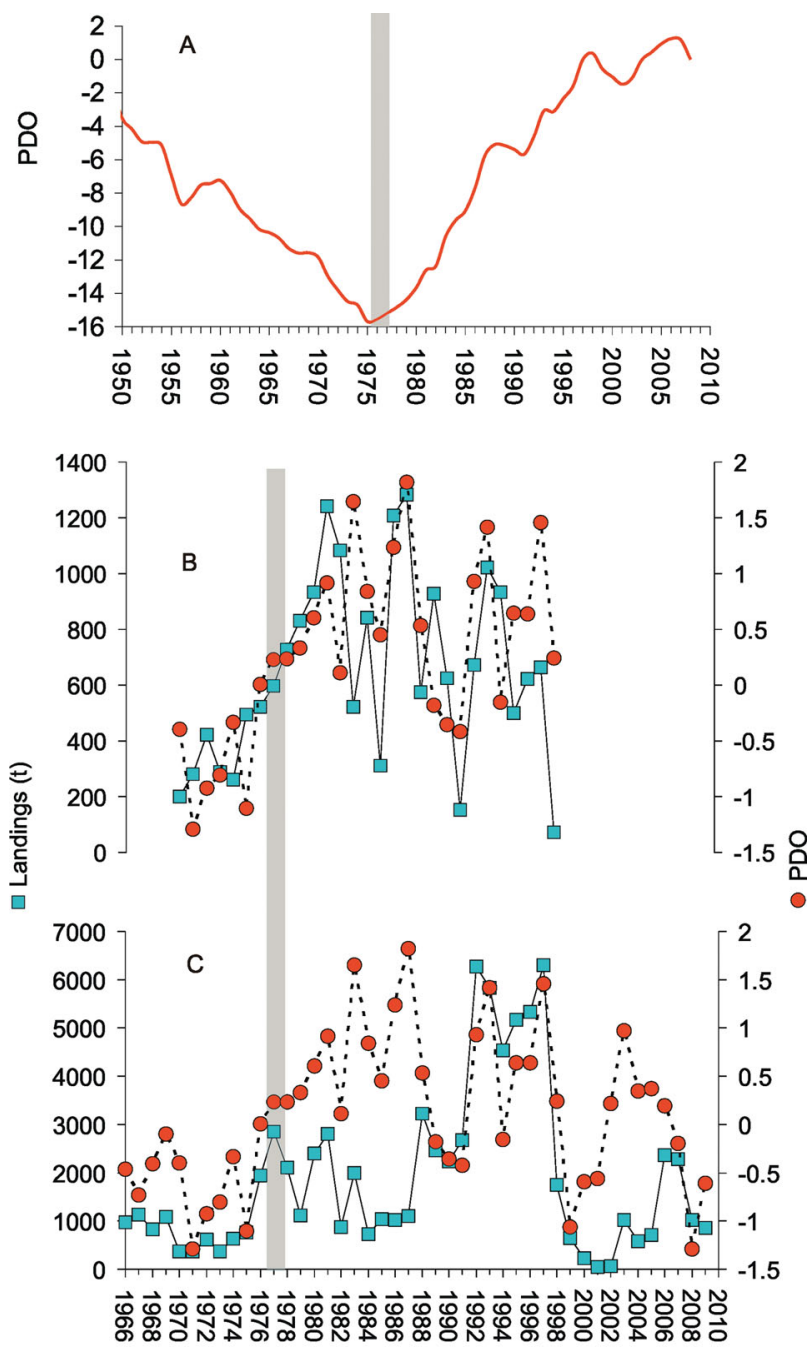

Fig. 2. Mesodesma donacium. (A) Cumulative sum of the Pacific Decadal Oscillation (PDO) index; and long-term variations in landings $(\square)$ and in the PDO (O) for (B) Peru and (C) Northern Chile. Shaded bar: climate shift in 1977, according to Fiedler (2002) and Chavez et al. (2003). Note the different scales on the $x$-axes in $(A)$ and $(B, C)$, and in the left-hand $y$-axes in $(B, C)$ 

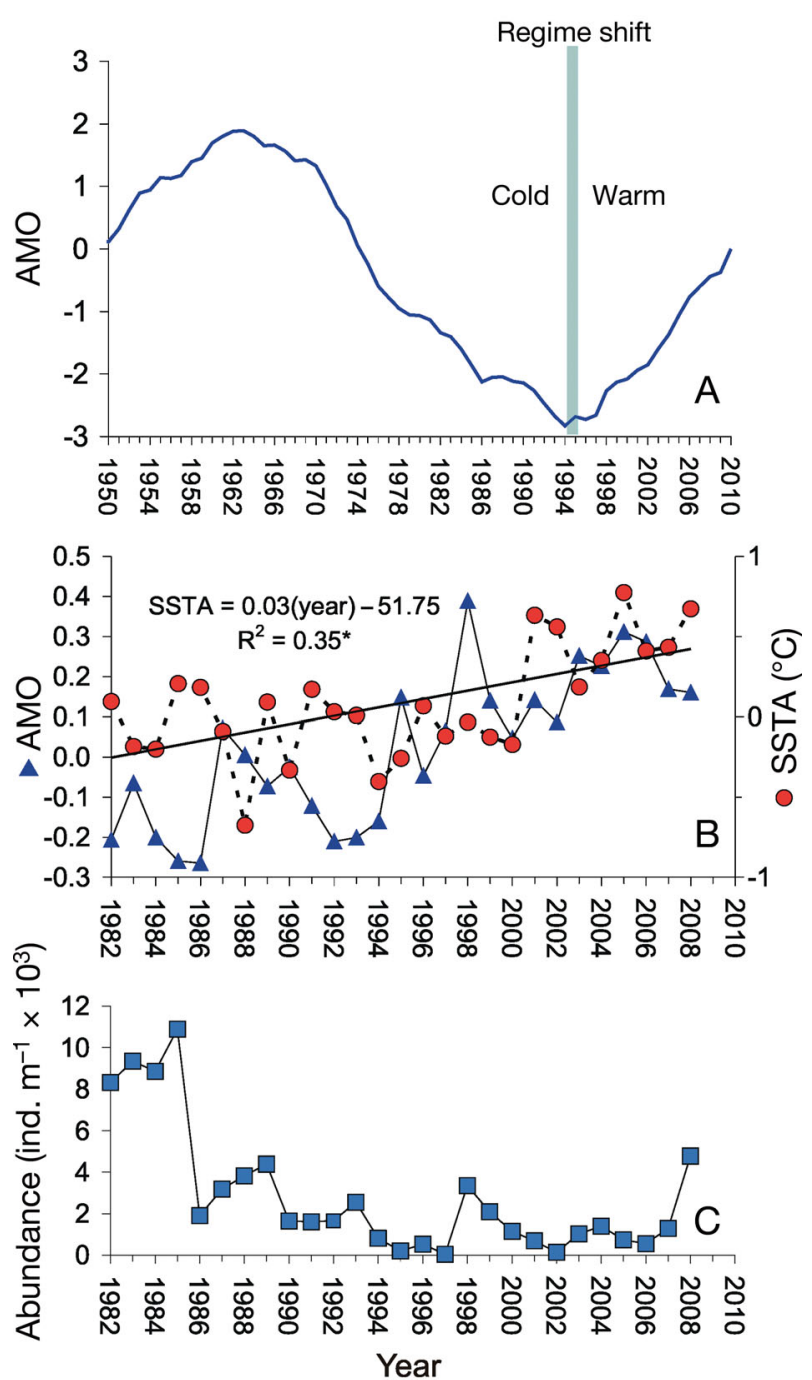

Fig. 3. (A) Cumulative sum of Atlantic Multidecadal Oscillation (AMO) from 1950 to 2008; (B) annual variations in sea surface temperature anomalies (SSTA, O) and AMO $(\boldsymbol{\Delta})$ for the period 1982 to 2008; (C) long-term variations in abundance of Mesodesma mactroides, from sampling surveys conducted between 1982 and 2008. The regression equation in (B) corresponds to the models fitted between SSTA and time (years) $\left({ }^{*} p<0.001\right)$. Shaded bar in $(\mathrm{A})$ : shift in the oceanclimate regime from a cold to a warm period between 1994 and 1995 (see Goldenberg et al. 2001 for details on this shift)

\section{Interannual coastal scale}

\section{Mesodesma donacium}

The Mesodesma donacium fishery in Peru showed an initial phase characterized by landings ranging between $200 \mathrm{t}$ in 1970 to $521 \mathrm{t}$ in 1976. The expansion phase occurred between 1977 and 1980, when catches reached ca. $4000 \mathrm{t}$, during the period preceding the strongest ENSO event, which occurred in 1982-83. This event caused mass mortalities, and no live surf clams were found in shallow waters south of Lima. After another strong warm ENSO event (1997-98), the fishery was closed (1999). This management decision is still in place in Peru (Fig. 4).

The macha fishery in Chile showed an initial fishery phase between 1966 and 1982, characterized by landings ranging between 1000 and 6000 t (Fig. 4). The expansion phase extended approximately between 1983 and 1989 (Fig. 4), as a response to a strong trend toward diversification in the exportation of many Chilean shellfish products. Landings peaked in 1989, reaching $\sim 18000 \mathrm{t}$, and drastically declined thereafter (1990 to 2006) down to $<4000$ t. The reduction in the exported volume from $2329 \mathrm{t}$ (1989) to 1641 t (1992) was compensated by a higher exportation price, reaching the highest export earnings in 1988 (US \$ 9381 000). Long-term variations in macha unit prices from Chile significantly increased through time, particularly between 1986 and 1988 and from 2002 to 2008 (Fig. 4).

All bioclimatic units showed oscillations in SSTA through time associated with cold and warm periods. With the exception of Peru, SSTA significantly increased through time (Fig. 5), with the highest temperatures observed during the strong ENSO events of 1982-83 and 1997-98 (shaded areas in Fig. 5). Landings in Peru drastically decreased from $4000 \mathrm{t}$ in 1978 to 500 t in 1983 (Fig. 6A). Between 1984 and 1997, landings were $\sim 800 \mathrm{t}$, and drastically dropped from 700 to $70 \mathrm{t}$ during the 1997-98 ENSO event. Since 1999, the fishery has been closed.

Concerning $\mathrm{NCh}$, the fishery showed a development phase between the 1960s and the mid-1970s, followed by an expansion phase that was interrupted in 1983 (ENSO). The fishery was recovered during the 1990s, reaching the highest historical value in 1997 (6000 t), and dramatically declined 1 yr later $(<2000 \mathrm{t})$, until reaching the lowest value in 2001 (45 t, see Fig. 5B). Concerning CCh, landings showed 2 peaks: the first was observed in the early 1970s, concurrently with a period of negative SSTA, whereas the second occurred in 1986 (7500 t), thereafter decreasing until reaching the lowest values after the 1997-98 ENSO (Fig. 5C). In SCh, landings also showed 2 major peaks (Fig. 5D): the main one in 1988-89 and the second one in 1998, during the ENSO event. A strong increase in landings occurred just after the ENSO of 1982-83, and was followed by an exponential drop during the 1990s (from 9000 to $<500$ t between 1993 and 1997). Landings increased 8-fold during the 1997-98 ENSO event (4000 t), but this pulse was followed by an exponential decrease, reaching $<2000 \mathrm{t} \mathrm{yr}^{-1}$ at the end of the period. 
GAM results are shown in Table 1. SSTA was a significant predictor of longterm variations in Peruvian landings (Table 1). Partial residuals showed a linear decrease through time and a nonlinear relationship with SSTA. In the latter, landings were highest at SSTA values close to $-1^{\circ} \mathrm{C}$, and dramatically declined with positive SSTA values (Fig. 6A). The decline in partial residuals through time suggests that the effect of SSTA alone was insufficient to change the observed trend in landings (Fig. S1A in the supplement at www.int-res.com/articles/ suppl/m469p071_supp.pdf). In $\mathrm{NCh}$, unit price was a significant nonlinear predictor of long-term variations in landings (Fig. 6B), but partial residuals showed a similar trend through time to that observed in raw data, particularly from 1976 onwards, when market statistics began, suggesting that the effect of market price was not the only explanatory variable of landing fluctuations (Table 1 ; Fig. S1B in the supplement).

For CCh, GAM results showed that price and SSTA were the best significant predictors $(p<0.01)$ of macha landings, as evidenced by the consistent increase in $\mathrm{r}^{2}$ and explained deviance, concurrently with a decrease in AIC (Table 1). Partial residuals followed a nonlinear decreasing relationship with unit price and a negative linear relationship with SSTA (Fig. 7A; Fig. S2A in the supplement). No statistical differences in residual deviance were observed $(\mathrm{p}(F)$

Table 1. Mesodesma donacium and M. mactroides. Generalized additive model selection, (GAM) for $M$. donacium landings and $M$. mactroides abundance. Non-significant terms $(p>0.05)$ were dropped from the model. Superscripts in the GAM column denote different models for the same region. The best model for each region and species is in bold. edf: estimated degrees of freedom; adj.: adjusted; DE: deviance explained; AIC: Akaike information criterion; s: spline smoother; Lan: landings; $A B$ : abundance; f: fishing effort; SSTA: sea surface temperature anomalies; CCh: Central Chile; NCh: Northern Chile; SCh: Southern Chile; Uy: Uruguay

\begin{tabular}{|c|c|c|c|c|c|}
\hline GAM & Terms & edf & Adj. $r^{2}$ & DE (\%) & $\mathrm{AIC}$ \\
\hline Peru & Lan $\sim$ s(Year) + s(SSTA) & 3.70 & 0.36 & 44.7 & 463 \\
\hline NCh & Lan $\sim$ s(Year) + s(Price) & 8.98 & 0.91 & 94.0 & 494 \\
\hline $\mathrm{CCh}^{1}$ & Lan $\sim$ s(Year $)+s($ Price $)+s($ SSTA $)$ & 9.01 & 0.94 & 95.8 & 486 \\
\hline $\mathrm{CCh}^{2}$ & Lan $\sim \mathrm{s}($ Year $)+\mathrm{s}$ (Price) & 8.06 & 0.92 & 94.1 & 495 \\
\hline $\mathrm{CCh}^{3}$ & Lan $\sim \mathrm{s}($ Year $)+\mathrm{s}(\mathrm{SSTA})$ & 9.34 & 0.92 & 94.7 & 494 \\
\hline $\mathbf{S C h}^{1}$ & Lan $\sim($ Year $)+($ Price $)+$ s(SSTA $)$ & 11.27 & 0.82 & 88.8 & 537 \\
\hline $\mathrm{SCh}^{2}$ & Lan (Year) + (Price) & 10.27 & 0.77 & 84.8 & 545 \\
\hline $\mathrm{SCh}^{3}$ & Lan $\sim$ (Year) + (SSTA) & 1.85 & 0.19 & 24.2 & 580 \\
\hline $\mathrm{Uy}^{1}$ & $\mathrm{AB} \sim \mathrm{s}($ Year $)+\mathrm{s}(\mathrm{f})+\mathrm{s}(\mathrm{SSTA})$ & 9.01 & 0.94 & 96.0 & 410 \\
\hline $\mathrm{Uy}^{2}$ & $\mathrm{AB} \sim \mathrm{s}($ Year $)+\mathrm{s}(\mathrm{f})$ & 4.57 & 0.88 & 90.4 & 424 \\
\hline
\end{tabular}

$=0.18)$ between the model with price $\left(\mathrm{GAM} \mathrm{CCh}{ }^{2}\right)$ and the one with SSTA $\left(\mathrm{GAM} \mathrm{CCh}^{3}\right)$ (Table 1), meaning that both variables have the same importance as predictors of long-term trends. However, the shape of the curve of partial residuals through time did not differ from the one observed with raw data, indicating that market price and SSTA cannot explain entirely the observed trends. The effect of market price is noticeable in partial residuals of the model: removing the effect of market price determined a change in the relationship between landings and SSTA (Fig. S3 in the supplement).

Concerning $\mathrm{SCh}$, unit price and SSTA were also the best significant predictors $(p<0.01)$ of long-term macha landings. Partial residuals showed a nonlinear negative relationship with unit price and, in contrast with the other bioclimatic units, a positive linear relationship with SSTA (Figs. 7B, S2B). The model that included only unit price $\left(\mathrm{GAM} \mathrm{SCh}{ }^{2}\right)$ explained a higher percentage of deviance, and had a lower AIC and lower residual deviance $(\mathrm{p}(F)$ $<0.001)$ than the model that only included SSTA (GAM SCh${ }^{3}$ ) (Table 1). Partial residuals showed a similar trend through time to that observed in raw data, indicating that the effect of market price and SSTA cannot explain entirely the observed trend in landings. Further analyses performed by modeling macha landings versus price (only for Chile, for which price information is available) showed that this relationship was significant for all 3 


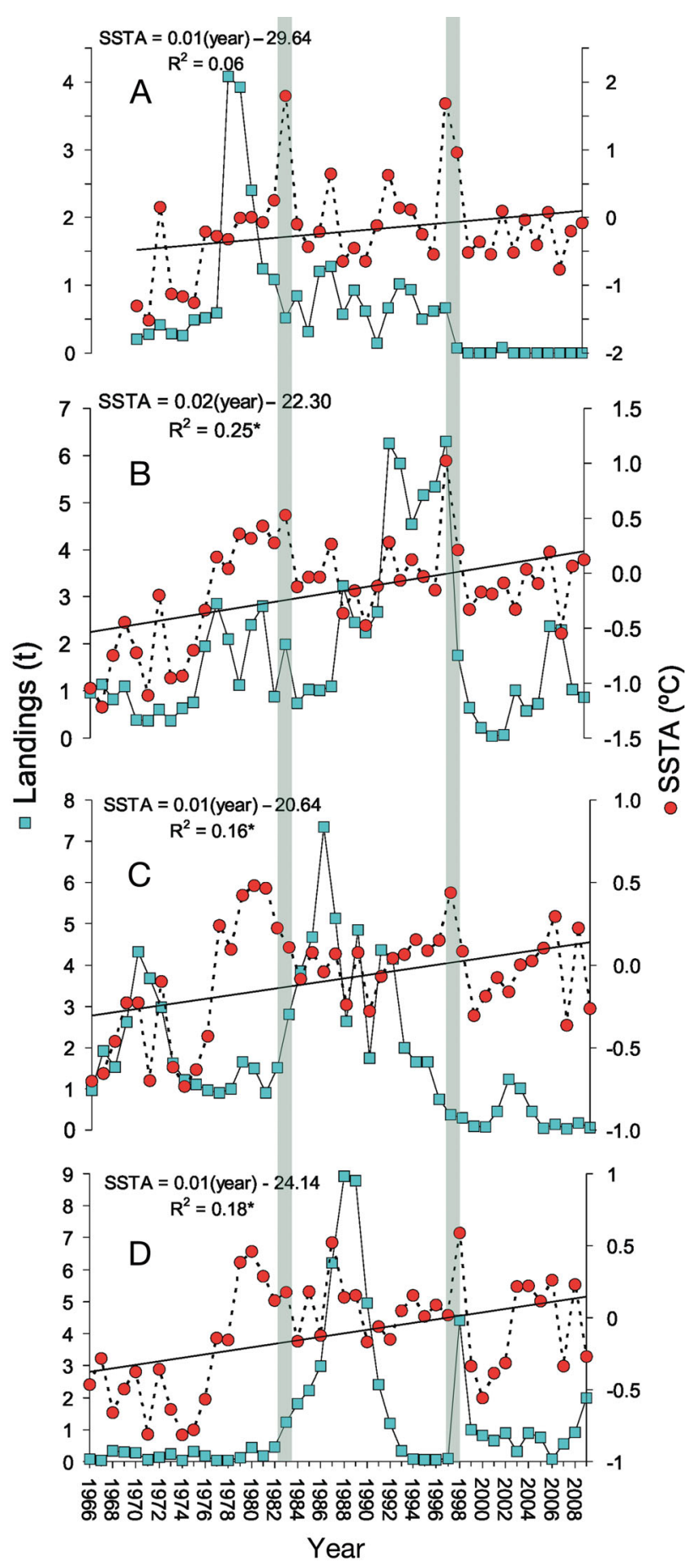

Fig. 5. Mesodesma donacium. Annual landings ( $\square$ ) and regional annual mean sea surface temperature anomalies (SSTA) (O) for (A) Peru, (B) Northern Chile, (C) Central Chile, and (D) Southern Chile. Shaded bars: strong El Niño Southern Oscillation (ENSO) events of 1982-83 and 199798, which matched with the highest SSTA and a decrease in landings in Peru and Northern Chile. The regression equations correspond to the models fitted between SSTA and time (year) $\left({ }^{*} p<0.001\right)$. Note the different scales for both the right- and left-hand $y$-axes
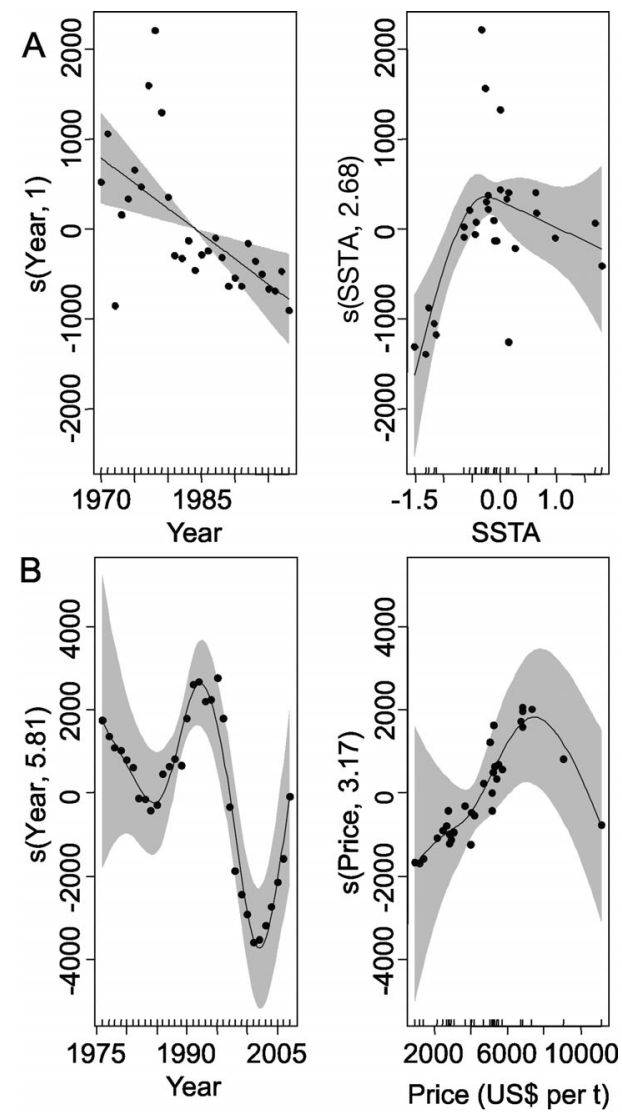

Fig. 6. Mesodesma donacium. Estimated generalized additive model (GAM) terms showing the partial residuals (solid lines) of annual landings after fitting against (A) time (year) and sea surface temperature anomalies (SSTA) in Peru; and (B) time (year) and price in Northern Chile. Shaded area: \pm 2 SE above and below the estimated smooth curve. Numbers on each $y$-axis are the estimated degrees of freedom of the plotted terms (partial residuals of landings)

Chilean regions (Table $\mathrm{S} 1$ in the supplement). The relationship between model residuals and SSTA was not significant for $\mathrm{NCh}$ and $\mathrm{SCh}$, whereas a negative relationship $\left(\mathrm{r}^{2}=0.16, \mathrm{p}<0.05\right)$ was found for $\mathrm{CCh}$ (Fig. S4A in the supplement).

\section{Mesodesma mactroides}

The long-term analysis of the artisanal yellow clam fishery in Uruguay showed a initial phase during early 1980s, followed by an overexploitation phase and the closure of the fishery in 1987 (Fig. 8A). An increase in unit price was observed through time, even at low landing and abundance levels (Fig. 8A). The best unit price-catch relationship followed a function of the form $\left(\mathrm{r}^{2}=0.78 ; \mathrm{p}<0.001\right)$ : Price $=$ $19.33 \times \mathrm{Catch}^{-0.63}$. The percentage of the harvestable 

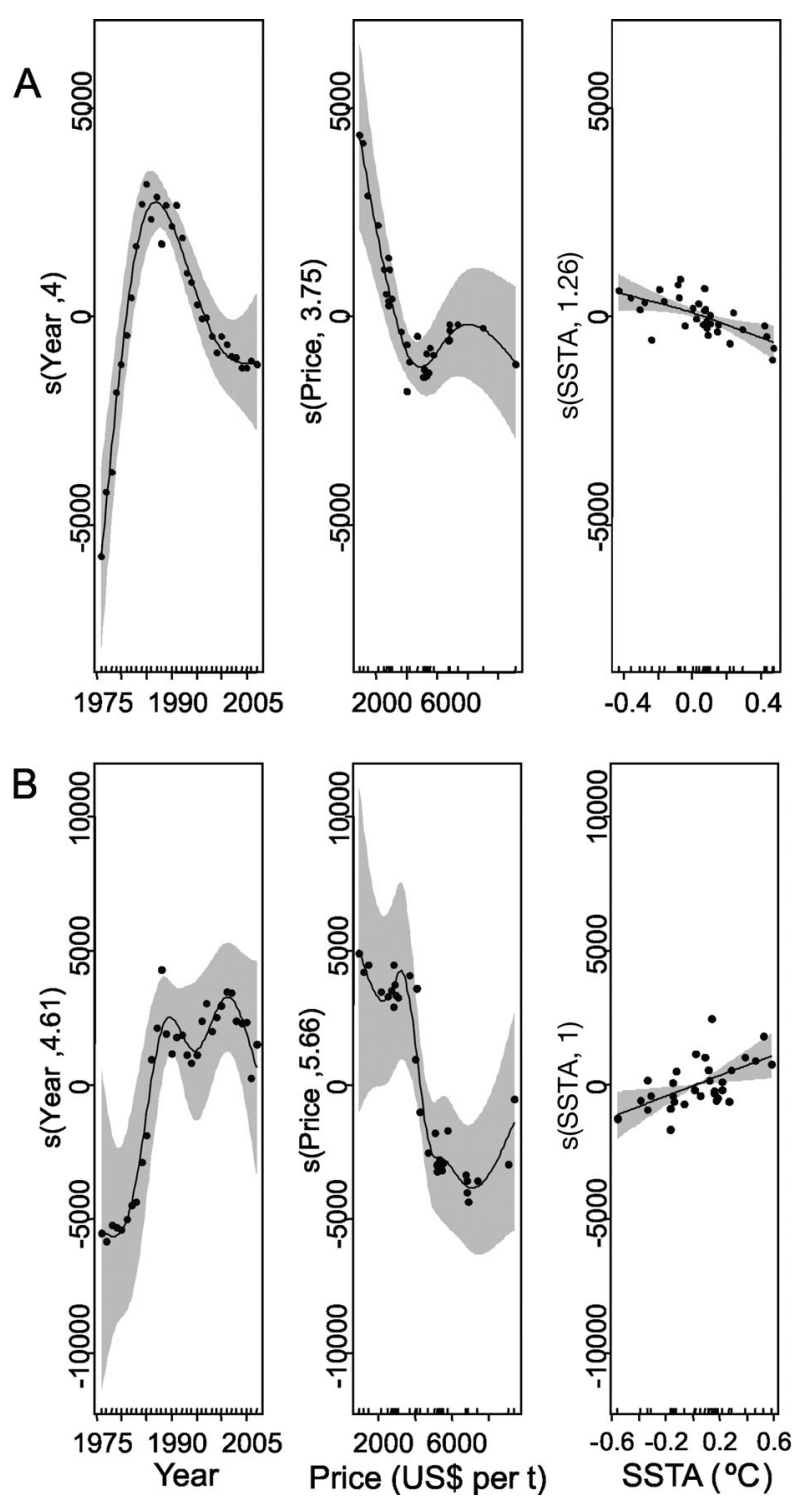

Fig. 7. Mesodesma donacium. Estimated generalized additive model (GAM) terms showing the partial residuals of annual landings (solid lines) after fitting against time (years), price, and sea surface temperature anomalies (SSTA) for (A) Central Chile and (B) Southern Chile. Shaded areas: \pm 2 SE above and below the estimated smooth curve. Numbers on each $y$-axis are the estimated degrees of freedom of the plotted terms (partial residuals of landings). Note the different scales

(adult abundance) significantly increased between 1989 and 1994, just after the fishery closure (1987 to 1989). However, the occurrence of several mass mortality events that began in late 1993 determined a new fishery closure until 2008, without showing evidence of stock recovery throughout this period, particularly in the case of the adult (harvestable) stock (Fig. 8B).

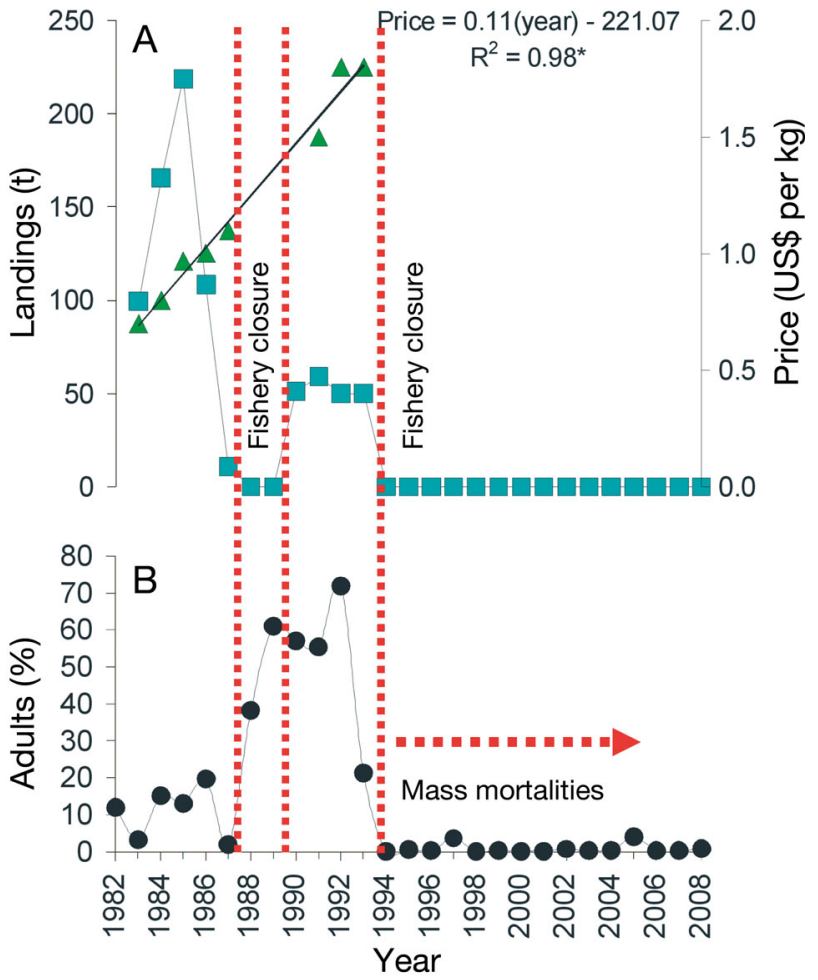

Fig. 8. Mesodesma mactroides. Long-term variations in: (A) landings ( $\square$ ) and unit price $(\mathbf{\Delta})$; and (B) the harvestable stock, as denoted by the percentage of adults ( ). The regression equation in (A) corresponds to the linear model fitted between unit price and time (year) $\left({ }^{*} \mathrm{p}<0.001\right)$. The red arrow highlights the beginning of mass mortalities since 1993-94 (see Fiori et al. 2004 for details on mass mortalities)

Fishing effort exerted in the previous year and SSTA were the best predictors of yellow clam abundance (Fig. 9, Fig. S5 in the supplement, Table 1). Partial residuals showed a positive relationship with fishing effort and 2 contrasting trends with SSTA: a positive nonlinear relationship with negative SSTA and a negative one with positive SSTA. Partial residuals through time showed the same pattern as for abundance, indicating that the effect of fishing effort and SSTA are insufficient to explain temporal variations in yellow clam abundance. The relationship between abundance and fishing effort was statistically significant (Table S1 in the supplement). The residuals of the model were negatively correlated with SSTA $\left(r^{2}=0.19 ; p<0.05\right)$ (Fig. S4B in the supplement).

\section{DISCUSSION}

This paper gives evidence of long-term and largescale effects of fishery bioeconomic factors and climate variability in intertidal sandy beach clams. The 

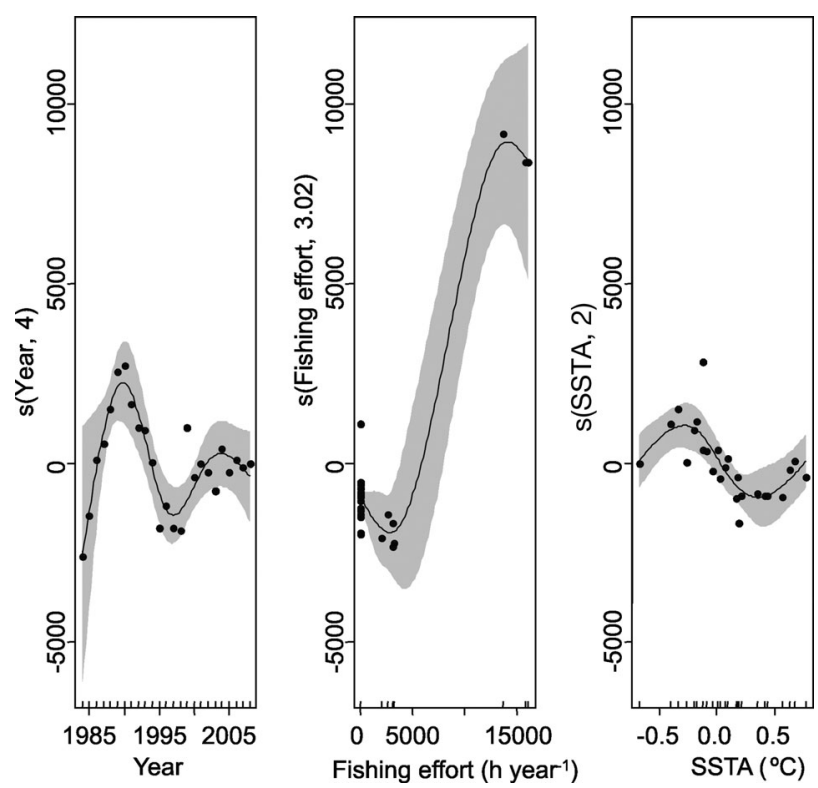

Fig. 9. Mesodesma mactroides. Estimated generalized additive model (GAM) terms showing the partial residuals (solid lines) of abundance after fitting against time (year), fishing effort exerted in the previous year, and sea surface temperature anomalies (SSTA). Shaded areas: \pm 2 SE above and below the estimate of the smooth curve. Numbers on each $y$ axis are the estimated degrees of freedom of the plotted term (partial residuals of abundance)

effect of these variables on Mesodesma donacium and $M$. mactroides clam fisheries was complex and varied in a differential way according to latitude and the intrinsic characteristics of the oceanographic systems. In this setting, the nature and sign of the relationship between Pacific macha landings and explanatory predictors varied by bioclimatic unit. Indeed, Peruvian landings were negatively correlated with SSTA and appeared to be dramatically affected by ENSO events (particularly 1997-98). By contrast, landings in SCh were positively and significantly correlated with SSTA, suggesting that species abundance could respond positively to slight increases in temperature at its southernmost distribution range. Our findings reinforce the notion that systems can respond in different ways to changes in drivers such as exploitation pressure or temperature rise (Scheffer et al. 2009). Even though our modeling approach was useful to assess the effects of market price, fishing effort, and climate on long-term trends in landings or abundance of sandy beach clams, it is not suitable for predictive proposes. In this vein, modeling catastrophic events (mass mortalities) needs another approach that is far beyond the scope of the present paper.
The dramatic drop in landings at the northernmost edge of the Mesodesma donacium range (Peru) and in $\mathrm{NCh}$, observed during or close to strong ENSO events, supports the notion that ENSO constitutes an important natural threat for the macha in the northernmost bioclimatic unit. ENSO is the major intradecadal and large-scale climate-driven forcing factor in the Chilean-Peruvian coastal upwelling system (Baumgartner \& Ortlieb 2002, Chavez et al. 2003, Montecino \& Lange 2009), causing dramatic changes in faunal assemblages (e.g. Barber \& Chavez 1983, Castilla \& Camus 1992, Chavez et al. 1999, Tarazona \& Arntz 2001), and affecting the domestic economy of Chile and Peru (Thatje \& Heilmayer 2008), including artisanal fisheries (see Castilla \& Camus 1992). In addition, the fast boom-and-bust cycle of the fishery in Peru aggravated the situation, suggesting that cumulative impacts of climate and fishing could have prompted the fishery collapse.

The inverse relationship between landings and temperature should be seen as a threshold where other processes took place. The increase in SSTA through time and the occurrence of ENSO events might have challenged Mesodesma donacium by distancing populations from optimal environmental conditions, operating directly through physiological processes (metabolism or reproduction) or indirectly through related changes in ecosystem structure (Stenseth et al. 2002). In this vein, mass M. donacium mortalities that occurred during strong warm ENSO events have been mainly associated with rising temperatures and increasing susceptibility to parasitism and diseases under anomalous environmental conditions (Arntz et al. 1987, Ibarcena et al. 2005, Riascos et al. 2009, 2011). These mass mortalities, which mainly occurred at the northernmost bioclimatic unit, generated drastic changes in the ecosystem and in the macrofaunal community structure, including increasing densities of subordinate competitors, such as the clam Donax obesulus (Arntz et al. 1987, Carstensen et al. 2010).

Mesodesma donacium landings in SCh increased under positive SSTA and during ENSO events, showing an opposite pattern to that observed for the northernmost edge. These trends suggest positive effects of increasing temperatures on clam abundance or fishery activity in this bioclimatic unit, which could be explained by 3 non-mutually exclusive hypotheses: (1) an increase in temperature in an actually cold system, together with a southward weakening of ENSO environmental effects and an improvement in climatic conditions; (2) a 'miningshellfish exploitation strategy' behavior (sensu Defeo 
\& Castilla 2005), where fishers and divers sequentially move into less-exploited clam beds (i.e. from $\mathrm{NCh}$ to $\mathrm{SCh}$ ); and (3) the existence of a genetic structure along geographic distribution of the species, with 2 groups of haplotypes and a contact zone between $32^{\circ}$ and $34^{\circ} \mathrm{S}(\mathrm{CCh})$, which could explain different responses to climate variability (Peralta 2008). Populations at the edges of a species range could have particular adaptations to extreme conditions, but climate changes make them even more vulnerable to fishing activity. From a management and conservation point of view, this means that special protection should be placed on these populations, where the first adverse environmental impacts are expected to occur (e.g. Peru and NCh). As the rate of change may overwhelm the ability of a species to adapt, a policy of 'managed retreat' (Brander 2010) should be needed. Indeed, a main implication of these trends is that efforts to reduce the risk of unwanted state shifts should address the gradual changes that affect resilience (Scheffer et al. 2001).

Long-term abundance fluctuations in the Atlantic yellow clam clearly showed that environmental effects, reflected by a systematic increase in SSTA, in addition to uncontrolled fishing at the beginning of the study period, have swamped management measures. Indeed, the fishery closure implemented between 1987 and 1989 allowed a fast and strong recovery of the harvestable (adult) stock (Defeo 1996, 1998; our Fig. 8). The fishery was reopened from December 1989 onwards, under a co-management scheme and a precautionary approach that included several management regulations (Defeo 1998). During the co-management phase, harvestable stock abundance increased and catch per unit effort (CPUE) was much higher than in preclosure years (see our Fig. 8B; Castilla \& Defeo 2001). However, the occurrence of mass mortalities registered from 1994 onwards decimated the stock, which has not fully recovered since then (see our Fig. 8B; Defeo 2003). A similar situation was observed in Brazil and Argentina (Fiori \& Defeo 2006, Herrmann et al. 2011). These mass mortalities sequentially occurred in a north-south direction from 1993 (southern Brazil) to 2002 (Isla del Jabali, Argentina), mainly between late spring and early summer, when these cold-water clams are more sensitive to diseases (Fiori et al. 2004). It is hypothesized that the systematic increase in SSTA, associated with a southward migration of a critical warm isotherm, has exacerbated the negative influence of oceanic warm waters (L. Ortega et al. unpubl.). Concurrently with the systematic increase in SSTA, long-term increasing effects of diseases and deformities (e.g. foot and gills) have been observed in this clam (Fiori et al. 2004, E. Delgado et al. unpubl.).

Regional warming could also have triggered drastic long-term changes in Atlantic sandy beach communities: mass mortalities of yellow clam promoted an exponential increase of warm-favoring species, such as the wedge clam Donax hanleyanus and the mole crab Emerita brasiliensis, which are subordinate competitors for space and food in this suspension-feeding guild (Defeo 2003). This shift that occurred in the ecosystem after a surpassing a critical threshold or tipping point has been observed in sandy beach ecosystems from southern Brazil, Uruguay (Defeo 2003), and Argentina (Dadón 2005, Herrmann et al. 2009, Thompson \& Sánchez De Bock 2009).

We found a significant effect of broad-scale climate variations on both clam fisheries. Tropical SSTA variations are in phase with $\mathrm{AMO}$, which adds support to the evidence that AMO influences South American climate (Seager et al. 2010). In the Uruguayan coast, the positive correlation between SSTA and the AMO suggests that the latter could also affect circulation patterns. In fact, the observed shift from a cold to a warm phase after 1994, the sustained rise in temperature in the SW Atlantic, the southward range shift of tropical species (Segura et al. 2009, Izzo et al. 2010), and the mass mortalities observed since 1993 reinforce the hypothesis of changing of circulation patterns. These effects have been mainly documented in the northern Atlantic (Beaugrand 2004, Gröger \& Fogarty 2011), whereas catch fluctuations in the southern Atlantic have been associated with unidentified low-frequency oceanographic anomalies and overfishing (e.g. Brazilian sardine; Matsuura 1996).

In the HCS, biological and non-biological components, ecosystem processes, and fisheries are known to be affected by multidecadal scale variations. In fact, air and ocean temperatures, atmospheric carbon dioxide, landings of pelagic fish, and the productivity of coastal and open ocean ecosystems have varied over periods of about 25 to $50 \mathrm{yr}$ (Montecino \& Lange 2009). In the mid-1970s, the Pacific changed from a cold to a warm regime (see Fig. 2A). A shift back to a cold regime occurred in mid to late 1990s (our Fig. 2B,C; Chavez et al. 2003). These basin-scale climate shifts might have influenced $\mathrm{NCh}$ and Peru Mesodesma donacium landings, with a positive response during the warm phase and a decline during the cold phase, concurrently with the 1997-98 ENSO. The prevailing hypothesis is that the PDO is caused by a 'reddening' (oceanic or other slow components of the climate system outside the domain of 
study) of ENSO events, combined with stochastic atmospheric forcing, which goes against the idea that PDO may regulate decadal climate variability (Newman et al. 2003, Pavia 2009, Shakun \& Shaman 2009). Consequently, the PDO could be seen as a consequence of past accumulated ENSO events that produce mild ENSO-like conditions in southern tropical Pacific coastal zones (i.e. deeper thermocline, positive SSTA, higher sea level). In contrast, high-frequency climate variations like ENSO, especially strong events, had dramatic negative effects on $M$. donacium at the northern Pacific bioclimatic units.

Unit price significantly increased through time in both Mesodesma clam fisheries. The steady increase in prices at low landing levels accelerated changes in resource use motivated by profit, suggesting that this variable constitutes a key economic driver that could lead to stock depletion. The growing demand associated with high export prices in $M$. donacium triggered an increase in fishing effort, which in turn affected stock sustainability. This response to market forcing was clearly shown in $\mathrm{NCh}$, where landings dropped after reaching a certain unit export price, probably masking the relationship with SSTA. A similar pattern was observed in the artisanal Peruvian bay scallop Argopecten purpuratus fishery (Badjeck et al. 2009). In Peru, the negative effects of ENSO (1982-83) on $M$. donacium were exacerbated by a high fishing intensity (1980 to 1981) and a sustained increase in global market demand (i.e. the southern Peru production of macha was exported to Chile; Ibarcena et al. 2005). In addition, the opening of $M$. donacium foreign markets (i.e. Spain) towards the selection of clam sizes lower than the legal marketable size has been observed (Defeo et al. 1993). Thus, overexploitation trends were aggravated by globalization of markets. The increase of prices even at low landing and abundance levels, observed in both Pacific and Atlantic Mesodesma fisheries, resemble the anthropogenic Allee effect, in which exploitation rates increase with decreasing population size or density (Courchamp et al. 2006, Berec et al. 2007). This phenomenon is particularly noticeable in coastal stocks artisanally harvested, such as the intertidal clams analyzed here, because price values of the exploited species largely exceed the negligible exploitation costs in easily and readily accessible fishing grounds (Defeo \& Castilla 2012). This highlights the need to consolidate institutional management responses, supported by integrative science, as a means to develop solid governance fishery systems to promote resilience under uncertainty (Thatje et al. 2008, Miller et al. 2010, Gutiérrez et al. 2011, Perry et al. 2011).
In summary, a complex combination of intensive exploitation, bioeconomic factors, and climate variability explained large-scale and long-term trends in landings and abundance of sandy beach clams. These factors acting together may accelerate the decline in the clams' abundance, leading them to population levels close to extinction. The lack of response of the stocks to drastic management measures (i.e. long-term closures) suggests that these complex social-ecological systems have exceeded critical thresholds (tipping points), shifting abruptly from one state to another through a catastrophic bifurcation that propels the system through a phase of directional change towards a contrasting state (Scheffer et al. 2009). Early warnings of climate tipping points (Lenton et al. 2008, Scheffer et al. 2009, Lenton 2011) could provide information to help manage sandy beach ecosystems that are increasingly threatened by long-lasting and large-scale stressors (Defeo \& McLachlan 2005, Schlacher et al. 2007, Defeo et al. 2009).

Acknowledgements. This paper is part of the $\mathrm{PhD}$ thesis of L.O. We thank the 'Benthic Ecology Group' of UNDECIMAR for field and laboratory assistance. Financial support was provided by The Pew Charitable Trust to O.D., DINARA (Food and Agriculture Organization (FAO) and Global Environmental Facility (GEF) projects), Agencia Nacional de Investigación e Innovación (ANII), and Programa de Desarrollo de las Ciencias Básicas (PEDECIBA). J.C.C. acknowledges financial support from, Ministerio de Economía, Fomento y Turismo, Chile. C. H. Peterson and 2 anonymous referees provided useful comments that improved the manuscript.

\section{LITERATURE CITED}

Álamo V, Valdivieso V (1997) Lista sistemática de moluscos marinos del Perú, 2nd edn. Instituto del Mar del Perú, $183 \mathrm{p}$

Arntz WE, Brey T, Tarazona J, Robles A (1987) Changes in the structure of a shallow sandy-beach community in Peru during an El Niño event. In: Payne AI, Gulland JA, Bink KH (eds) The Benguela and comparable ecosystems. S Afr J Mar Sci 5:645-658

Badjeck MC, Mendo J, Wolff M, Lange H (2009) Climate variability and the Peruvian scallop fishery: the role of formal institutions in resilience building. Clim Change 94:211-232

Bakun A (1996) Patterns in the ocean: ocean processes and marine population dynamics. University of California Sea Grant, La Jolla, CA

Barber RT, Chavez FP (1983) Biological consequences of El Niño. Science 222:1203-1210

Baumgartner T, Ortlieb L (2002) Interdecadal and centennial variability underlying the El Niño/La Niña System. Invest Mar (Chile) 30:82-83

Beaugrand G (2004) The North Sea regime shift: evidence, causes, mechanisms and consequences. Prog Oceanogr 60:245-262 
Beck MW, Brumbaugh RD, Airoldi L, Carranza A and others (2011) Oyster reefs at risk and recommendations for conservation, restoration and management. Bioscience 61: 107-116

Beentjes MP, Carbines GD, Willsman AP (2006) Effects of beach erosion on abundance and distribution of toheroa (Paphies ventricosa) at Bluecliffs Beach, Southland, New Zealand. N Z J Mar Freshw Res 40:439-453

Berec L, Angulo E, Courchamp F (2007) Multiple Allee effects and population management. Trends Ecol Evol 22:185-191

Brander K (2010) Impacts of climate change on fisheries. J Mar Syst 79:389-402

Caddy JF, Defeo O (2003) Enhancing or restoring the productivity of natural populations of shellfish and other marine invertebrate resources. FAO Fish Tech Pap 448. Food and Agriculture Organization of the United Nations, Rome

Camus PA (2001) Biogeografía marina de Chile continental. Rev Chil Hist Nat 74:587-617

> Carranza A, Defeo O, Beck M (2009a) Diversity, conservation status and threats to native oysters (Ostreidae) around the Atlantic and Caribbean coasts of South America. Aquat Conserv Mar Freshw Ecosyst 19: 344-353

Carranza A, Defeo O, Beck M, Castilla JC (2009b) Linking fisheries management and conservation in bioengineering species: the case of South American mussels (Mytilidae). Rev Fish Biol Fish 19:349-366

Carstensen D, Riascos JM, Heilmayer O, Arntz WE, Laudien J (2010) Recurrent, thermally-induced shifts in species distribution range in the Humboldt current upwelling system. Mar Environ Res 70:293-299

Castilla JC, Camus PA (1992) The Humboldt El Niño Scenario: coastal benthic resources and anthropogenic influences, with particular reference to the 1982/83 ENSO. S Afr J Mar Sci 12:703-712

> Castilla JC, Defeo O (2001) Latin American benthic shellfisheries: emphasis on co-management and experimental practices. Rev Fish Biol Fish 11:1-30

Chavez FP, Strutton PG, Friederich GE, Feely RA, Feldman GA, Foley D, McPhaden MJ (1999) Biological and chemical response of the equatorial Pacific Ocean to the $1997-$ 98 El Niño. Science 286:2126-2131

> Chavez FP, Ryan J, Lluch-Cota SE, Niquen CM (2003) From anchovies to sardines and back: multidecadal change in the Pacific Ocean. Science 299:217-221

> Courchamp F, Angulo E, Rivalan P, Hall R, Signoret L, Bull L, Meinard Y (2006) Rarity value and species extinction: the anthropogenic Allee effect. PLoS Biol 4:e415

Cury PM, Shin YJ, Planque B, Durant JM and others (2008) Ecosystem oceanography for global change in fisheries. Trends Ecol Evol 23:338-346

Dadón JR (2005) Changes in the intertidal community structure after a mass mortality event in sandy beaches of Argentina. Contrib Zool 74:27-39

Defeo O (1996) Experimental management of an exploited sandy beach bivalve population. Rev Chil Hist Nat 69: $615-630$

Defeo O (1998) Testing hypotheses on recruitment, growth and mortality in exploited bivalves: an experimental perspective. Can Spec Publ Fish Aquat Sci 125:257-264

Defeo O (2003) Marine invertebrate fisheries in sandy beaches: an overview. J Coast Res 35(Spec Issue): $56-65$
Defeo O, Castilla JC (2005) More than one bag for the world fishery crisis and keys for co-management successes in selected artisanal Latin American shellfisheries. Rev Fish Biol Fish 15:265-283

> Defeo O, Castilla JC (2012) Governance and governability of coastal shellfisheries in Latin America and the Caribbean: multi-scale emerging models and effects of globalization and climate change. Curr Opin Environ Sustain 4:344-350

> Defeo O, McLachlan A (2005) Patterns, processes and regulatory mechanisms in sandy beach macrofauna: a multiscale analysis. Mar Ecol Prog Ser 295:1-20

Defeo O, de Alava A, Valdivieso V, Castilla JC (1993) Historical landings and management options for the genus Mesodesma in coast of South America. Biol Pesq (Chile) 22:4-54

> Defeo O, McLachlan A, Schoeman DS, Schlacher T and others (2009) Threats to sandy beach ecosystems: a review. Estuar Coast Shelf Sci 81:1-12

> Dugan JE, Defeo O, Jaramillo E, Jones AR and others (2010) Give beach ecosystems their day in the sun. Science 329: 1146

Enfield DB, Mestas-Nunez AM, Trimble PJ (2001) The Atlantic multidecadal oscillation and its relation to rainfall and river flows in the continental US Geophys Res Lett 28:2077-2080

Fiedler PC (2002) Environmental change in the eastern tropical Pacific Ocean: review of ENSO and decadal variability. Mar Ecol Prog Ser 244:265-283

Fiori S, Defeo O (2006) Biogeographic patterns in life-history traits of the yellow clam, Mesodesma mactroides, in sandy beaches of South America. J Coast Res 22:872-880

Fiori S, Vidal-Martínez V, Simá-Álvarez R, Rodríguez-Canul R, Aguirre-Macedo ML, Defeo O (2004) Field and laboratory observations of the mass mortality of the yellow clam Mesodesma mactroides in South America: the case of Isla del Jabalí, Argentina. J Shellfish Res 23:451-455

Goldenberg SB, Landsea CW, Mestas-Nuñez AM, Gray WM (2001) The recent increase in Atlantic hurricane activity: causes \& implications. Science 293:474-479

Gröger JP, Fogarty MJ (2011) Broad-scale climate influences on cod (Gadus morhua) recruitment on Georges Bank. ICES J Mar Sci 68:592-602

Guerrero RA, Piola AR, Molinari GN, Osiroff AP, Jáuregui SI (2010) Climatología de la temperatura y salinidad en el Río de la Plata y su Frente Marítimo. Argentina-Uruguay. Instituto Nacional de Investigación y Desarrollo Pesquero (INIDEP), Mar del Plata

Gutiérrez N, Hilborn R, Defeo O (2011) Leadership, social capital and incentives promote successful fisheries. Nature 470:386-389

Hastie T, Tibshirani R (1990) Generalized additive models. Chapman \& Hall, London

Herrmann M, Carstensen D, Fischer S, Laudien J, Penchaszadeh PE, Arntz WE (2009) Population structure, growth, and production of the wedge clam Donax hanleyanus (Bivalvia: Donacidae) from northern Argentinean beaches. J Shellfish Res 28:511-526

Herrmann M, Alfaya J, Lepore M, Penchaszadeh P, Arntz W (2011) Population structure, growth and production of the yellow clam Mesodesma mactroides (Bivalvia: Mesodesmatidae) from a high-energy, temperate beach in northern Argentina. Helgol Mar Res 65:285-297

Ibarcena W, Muñante Angulo L, Muñante Melgar L, Vázquez J (2005) La explotación de la macha (Meso- 
desma donacium Lamarck 1818) en el litoral de Tacna. Cienc Desarr (Perú) 8:12-22

Izzo P, Milessi AC, Ortega L, Segura AM (2010) First record of Aluterus scriptus (Monacanthidae) in Mar del Plata, Argentina. Mar Biodivers Rec 3:e40 doi:10.1017/S17552 67210000369

Jaramillo E, Pino M, Fulin L, González M (1994) Longshore distribution of Mesodesma donacium (Bivalvia: Mesodesmatidae) on a sandy beach of the South of Chile. Veliger 37:192-200

Lenton TM (2011) Early warning of climate tipping points. Nat Clim Change 1:201-209

Lenton TM, Held H, Kriegler E, Hall JW, Lucht W, Rahmstorf S, Schellnhuber HJ (2008) Tipping elements in the Earth's climate system. Proc Natl Acad Sci USA 105: 1786-1793

Lima ID, Garcia CAE, Möller OO (1996) Ocean surface processes on the southern Brazilian shelf: characterization and seasonal variability. Cont Shelf Res 16:1307-1317

Ling SD, Johnson CR, Frusher SD, Ridgway KR (2009) Overfishing reduces resilience of kelp beds to climate-driven catastrophic phase shift. Proc Natl Acad Sci USA 106: 22341-22345

Marins LF, Levy JA (1999) High genetic distance between marine bivalves of the genus Mesodesma inhabiting the Atlantic and Pacific coasts of South America. Comp Biochem Physiol A 124:313-319

- Matsuura Y (1996) A probable cause of recruitment failure of the Brazilian sardine Sardinella aurita population during the 1974/75 spawning season. S Afr J Mar Sci 17: 29-35

McClanahan T, Castilla JC, White A, Defeo O (2009) Healing small-scale fisheries by facilitating complex socioecological systems. Rev Fish Biol Fish 19:33-47

McLachlan A, Dugan J, Defeo O, Ansell AD, Hubbard DM, Jaramillo E, Penchaszadeh PE (1996) Beach clam fisheries. Oceanogr Mar Biol Annu Rev 34:163-232

Miller K, Charles A, Barange M, Brander K and others (2010) Climate change, uncertainty, and resilient fisheries: institutional responses through integrative science. Prog Oceanogr 87:338-346

Montecino V, Lange CB (2009) The Humboldt Current System: ecosystem components and processes, fisheries, and sediment studies. Prog Oceanogr 83:65-79

> Newman M, Compo GP, Alexander MA (2003) ENSO-forced variability of the Pacific Decadal Oscillation. J Clim 16: 3853-3857

Odebrecht C, Rörig L, Gracia VT, Abreu PC (1995) Shellfish mortality and red tide event in southern Brazil. In: Lassus $\mathrm{P}$ (ed) Harmful marine algal blooms. Springer, New York, NY, p 213-218

Ortega L, Martínez A (2007) Multiannual and seasonal variability of water masses and fronts over the Uruguayan shelf. J Coast Res 23:618-629

Pavia EG (2009) The relationship between Pacific Decadal and Southern Oscillations: implications for the climate of northwestern Baja California. Geofis Int (Mexico) 48: 385-389

Peralta G (2008) Patrones filogeográficos en el bivalvo Mesodesma donacium Lamarck (1818) 'macha' en Chile. MSc thesis, Universidad de Chile, Santiago

Perry RI, Ommer RE, Barange M, Jentoft S, Neis B, Sumaila UR (2011) Marine social-ecological responses to environmental change and the impacts of globalization. Fish Fish 12:427-450
Piola A, Campos E, Möller O Jr, Charo M, Martinez C (2000) Subtropical shelf front off eastern South America. J Geophys Res 105:6565-6578

Podestá GP (1990) Migratory pattern of Argentina hake Merluccius hubbsi and oceanic processes in the Southern Atlantic Ocean. Fish Bull 88:167-177

R Development Core Team (2008) R: a language and environment for statistical computing. R Foundation for Statistical Computing, Vienna. www.R-project.org

> Reynolds RW, Rayner NA, Smith TM, Stokes DC, Wang W (2002) An improved in situ and satellite SST analysis for climate. J Clim 15:1609-1625

Riascos JM, Carstensen D, Laudien J, Arntz WE, Oliva ME, Güntner A, Heilmayer O (2009) Thriving and declining: climate variability shaping life-history and population persistence of Mesodesma donacium in the Humboldt Upwelling System. Mar Ecol Prog Ser 385:151-163

Riascos JM, Heilmayer O, Oliva ME, Laudien J (2011) Environmental stress and parasitism as drivers of population dynamics of Mesodesma donacium at its northern biogeographic range. ICES J Mar Sci 68:823-833

Rivadeneira MM, Santoro CM, Marquet PA (2010) Reconstructing the history of human impacts on coastal biodiversity in Chile: constraints and opportunities. Aquat Conserv Mar Freshw Ecosyst 20:74-82

Rouyer T, Fromentin JM, Ménard F, Cazelles B and others (2008) Complex interplays among population dynamics, environmental forcing, and exploitation in fisheries. Proc Natl Acad Sci USA 105:5420-5425

Scheffer M, Carpenter S, Foley JA, Folke C, Walker B (2001) Catastrophic shifts in ecosystems. Nature 413:591-596

Scheffer M, Bascompte J, Brock WA, Brovkin V and others (2009) Early-warning signals for critical transitions. Nature 461:53-59

Schlacher TA, Dugan J, Schoeman DS, Lastra M and others (2007) Sandy beaches at the brink. Divers Distrib 13: $556-560$

Seager R, Naik N, Baethgen W, Robertson A, Kushnir Y, Nakamura J, Jurburg S (2010) Tropical oceanic causes of interannual to multidecadal precipitation variability in Southeast South America over the past century. J Clim 23:5517-5539

Segura AM, Carranza A, Rubio LE, Ortega L, García M (2009) Stellifer rastrifer (Pisces: Sciaenidae): first Uruguayan records and a $1200 \mathrm{~km}$ range extension. Mar Biodivers Rec 2:e67 doi:10.1017/S1755267209000852

Seijo JC, Defeo O, Salas S (1998) Fisheries bioeconomics: theory, modelling and management. FAO Fish Tech Pap 368. Food and Agriculture Organization of the United Nations, Rome

- Shakun JD, Shaman J (2009) Tropical origins of North and South Pacific decadal variability. Geophys Res Lett 36: $1-5$

Spalding MD, Fox HE, Allen GR, Davidson N and others (2007) Marine ecoregions of the world: a bioregionalization of coastal and shelf areas. Bioscience 57:573-583

Stenseth NC, Mysterud A, Ottersen G, Hurrell JW, Chan KS, Lima M (2002) Ecological effects of climate fluctuations. Science 297:1292-1296

Tarazona J, Arntz WE (2001) The Peruvian coastal upwelling system. Ecol Stud 144:229-244

Tarifeño E (1980) Studies on the biology of the surf-clam Mesodesma donacium (Lamarck, 1818) (Bivalvia: Mesodesmatidae) from Chilean sandy beaches. PhD dissertation, University of California, Los Angeles 
Thatje S, Heilmayer O, Laudien J (2008) Climate variability and El Niño Southern Oscillation: implications for natural coastal resources and management. Helgol Mar Res 62(Suppl 1):5-14

Thiel M, Macaya EC, Acuña E, Arntz WE and others (2007) The Humboldt Current System of Northern and Central Chile: oceanographic processes, ecological interactions and socioeconomic feedback. Oceanogr Mar Biol Annu Rev 45:195-344

> Thompson GA, Sánchez De Bock MA (2009) Influence of beach morphodynamics on the bivalve Donax hanleyanus and Mesodesma mactroides populations in Argentina. PSZNI: Mar Ecol 30:198-211

Editorial responsibility: Charles Peterson,

Morehead City, North Carolina, USA von Ihering $H$ (1907) Les mollusques fossils du tertiare et du crétacé supérieur de l'Árgentine. Anales del Museo de Buenos Aires 3:1-611

Wood SN (2006) Generalized additive models: an introduction with R. Chapman \& Hall, London

Xiang D (2001) Fitting generalized additive models with the GAM procedure. Paper P256-26. SAS Institute, Cary, NC

Zavialov P, Wainer I, Absy J (1999) Sea surface temperature variability off southern Brazil and Uruguay as revealed from historical data since 1854. J Geophys Res 104: 21021-21032

Zhang Y, Wallace JM, Battisti DS (1997) ENSO-like interdecadal variability: 1900-93. J Clim 10:1004-1020

Submitted: February 13, 2012; Accepted: August 21, 2012

Proofs received from author(s): November 9, 2012 